\title{
„AKTUALNE ZAGADNIENIA POLSKIEGO PRAWA WYBORCZEGO” 57 ZJAZD KATEDR PRAWA KONSTYTUCYJNEGO. ZIELONA GÓRA, 17-19 WRZEŚNIA 2015 R.
}

57 Zjazd Katedr Prawa Konstytucyjnego został zorganizowany przez Katedrę Prawa Konstytucyjnego oraz Katedrę Systemów Ustrojowych i Praw Człowieka Wydziału Prawa i Administracji Uniwersytetu Zielonogórskiego.

Konferencja odbyła się pod patronatem Rektora Uniwersytetu Zielonogórskiego, prof. dr hab. inż. Tadeusza Kuczyńskiego, Pierwszej Prezes Sądu Najwyższego prof. dr hab. Małgorzaty Gersdorf, Przewodniczącego Naczelnego Sądu Administracyjnego prof. dr hab. Romana Hausera, Przewodniczącego Państwowej Komisji Wyborczej sędziego Wojciecha Hermelińskiego, Prezesa Krajowej Rady Notarialnej Mariusza Białeckiego, Marszałka Województwa Lubuskiego Elżbiety Polak, Prezydenta Zielonej Góry Janusza Kubickiego i Krajowej Rady Komorniczej.

Patronat medialny nad konferencją objął: „Monitor Prawniczy”, „Przegląd Prawa Konstytucyjnego”, „Humanistyczne Zeszyty Naukowe - Prawa Człowieka” oraz „Studia Wyborcze”.

W pierwszym dniu konferencji, po rejestracji uczestników, obrady prowadzone były w ramach 10 sesji panelowych. Pierwszy blok tematyczny, któremu przewodniczył dr Jarosław Zbieranek, został poświęcony szansom i wyzwaniom centrom studiów wyborczych. W dyskusji udział wzięli: prof. dr hab. Krzysztof Skotnicki, prof. nadzw. dr hab. Piotr Uziębło, dr Anna Rakowska-Trela i dr Anna Frydrych-Depka. Drugi panel, odbywający się pod przewodnictwem prof. dr hab. Krzysztofa Skotnickiego, dotyczył problematyki Państwowej Komisji Wyborczej. W tej części referaty wygłosili: dr Andrzej Pogódek i dr Bogusław Przywora (Państwowa Komisja Wyborcza - w poszukiwaniu modelu ustrojowego), dr Mariusz Bidziński (Kompetencje Państwowej Komisji Wyborczej w zakresie nadzoru i kontroli nad finansowaniem partii politycznych). Pod przewodnictwem dr hab. Moniki Florczak-Wątor odbył się z kolei panel pt. „Wybrane zagadnienia realizacji czynnego prawa wyborczego cz. I", w ramach którego wystąpili: prof. dr hab. Bronisław Sitek ( $Z a-$ sada tajności głosowania. Dyskurs pomiędzy historia a ciekawościa), dr Krzysz- 
tof Kozłowski (Instytucja głosowania przez petnomocnika a konstytucyjna zasada bezpośredniości wyborów - problem, który wciąż nie został rozwiazany), dr Robert Kropiwnicki (Glosowanie korespondencyjne w Kodeksie wyborczym) oraz dr Michał Zieliński (Racja bytu głosowania elektronicznego). Części drugiej tego panelu przewodniczył prof. nadzw. dr hab. Piotr Tuleja. Swoje referaty wygłosili wówczas: dr Paweł Kuczma (Przymus wyborczy), dr Monika Giżyńska (Niska frekwencja wyborcza a przymus wyborczy. Skuteczność i adekwatność), a także dr Anna Feja-Paszkiewicz (Uprawnienia wyborcze obywateli Unii Europejskiej niebędacych obywatelami polskimi w Rzeczypospolitej Polskiej). W panelu pod przewodnictwem prof. dr hab. Andrzeja Szmyta na temat zasad ustroju i prawa wyborczego głos zabrali: mgr Maciej Pach (O zasadzie podziału władzy w kontekście terminu zarzadzenia przez Prezydenta RP wyborów do Sejmu i Senatu/kilka uwag na marginesie wyroku K 9/11/), dr Krzysztof Urbaniak (Okręg wyborczy a realizacja zasady proporcjonalności i równości wyborów), dr Dobrochna Ossowska-Salamonowicz (Granice swobody wyrażania opinii w czasie kampanii wyborczej) oraz dr hab. Artur Ławniczak (Zasada wolnych wyborów). W kolejnym panelu poświęconemu powszechności wyborów i ekonomicznych aspektów wyborów, prowadzonemu pod przewodnictwem prof. nadzw. dr. hab. Dariusza Dudka, udział wzięli: dr Jacek Mazur (Publiczne szacowanie skutków makroekonomicznych programów wyborczych w niektórych krajach), dr Joanna Juchniewicz (Struktura wydatków komitetów wyborczych $w$ wyborach parlamentarnych), dr Ewa Tuora-Schwierskott (System wyborczy do Bundestagu w Republice Federalnej Niemiec. Połaczenie systemu wyborów jednomandatowych z systemem wyborów proporcjonalnych) i prof. dr hab. Bogusław Banaszak (Perspektywy wprowadzenia jednomandatowych okręgów wyborczych (JOW) w Polsce). W części obrad prowadzonej pod przewodnictwem prof. dr hab. Dariusza Góreckiego, poświęconej zagadnieniom prawa wyborczego, swoje wystąpienia wygłosili: dr Michał Bartoszewicz (Kilka uwag o ciszy wyborczej), dr Jarosław Zbieranek (Alternatywne procedury głosowania w polskim prawie wyborczym - gwarancja zasady powszechności wyborów czy mechanizm zwiększania frekwencji wyborczej?) oraz dr Maciej Borski (Granice agitacji wyborczej w kodeksie wyborczym - wybrane zagadnienia).

$\mathrm{W}$ ramach dwóch paneli edukacyjnych, którym przewodniczyli prof. dr hab. Stanisław Stadniczenko oraz prof. nadzw. dr hab. Pasquale Policastro, referaty przedstawili: prof. nadzw. dr hab. Pasquale Policastro (Rekursywne, indukcyjne, derywacyjne, intuicyjne, empatyczne myślenie a istota prawnego rozumowania: podstawy $i$ cele edukacji prawniczej $w$ społeczeństwie europejskim i globalnym), mgr Ewa Milczarek (Implementacja systemu bolońskiego dla studiów prawniczych w Polsce: perspektywa studenta i młodych pracowników naukowych), mgr Ewa Michałkiewicz (Urzeczywistnianie europejskich ram kwalifikacji dla edukacji prawniczej w Polsce a optymalizacja procesu nauczania: przygotowanie studentów prawa do zawodu poprzez streszczenie wyroków), mgr Anna Mylokosta (Urzeczywistnienie Europejskich Ram Kwalifikacji dla edukacji prawniczej w Polsce 
a optymalizacja procesu nauczania: przygotowanie studentów prawa do zawodu poprzez streszczenie aktów prawnych), dr Izabela Gawłowicz (Analiza rozsadnej ekwiwalencji treści programów studiów prawniczych w różnych krajach europejskich a ,European Credit Transfer System”), dr Sławomir Maciejewski (Czy metoda rekursywnego myślenia jest nadal optymalna dla tworzenia prac dyplomowych i naukowych $w$ dziedzinie prawniczej?), dr Joanna Osiejewicz (Ksztatcenie ttumacza a dostęp do sadu w perspektywie europejskiej), mgr Wojciech Bałaban (Uczenie się przez całe życie wobec umiędzynarodowienia zawodu prawnego: metody szybkiego i rzetelnego rozwiazywania problemów prawnych $w$ różnych językach) oraz mgr Małgorzata Frymus (Tworzenie materiałów audiowizualnych a prawo: problematyki konstytucyjno-prawne podczas wywiadów dla filmu dokumentalnego na przyktadzie filmu , Wielka Zielona Ściana: Afryka Afryce”).

Natomiast w ramach panelu w języku angielskim pod przewodnictwem prof. dr. Rainera Arnolda wystąpienia wygłosili: prof. dr Gaetano Dammacco (The right of minorities and democratic participation in the electoral law), prof. dr Eugen Chelaru oraz Dr. Andra Puran (Romanian electoral system. Present and perspectives), prof. dr Cristina Hermida del Llano (Reflections on the Spanish electoral system), a także prof. dr Raffaele Guido Rodio (The fundamental principles of the Italian electoral system in the Constitutional Court judgment n. 1/2014).

Do uroczystego otwarcia obrad doszło w dniu następnym, kiedy to zgromadzonych uczestników przywitał dziekan Wydziału Prawa i Administracji Uniwersytetu Zielonogórskiego, prof. dr hab. Bogusław Banaszak.

W ramach dwóch sesji plenarnych, którym przewodniczyli odpowiednio prof. dr hab. Małgorzata Gersdorf oraz prof. dr hab. Ewa Gdulewicz, swoje wystąpienia zaprezentowali: prof. dr hab. Andrzej Rzepliński (Wolne wybory), prof. dr hab. Jacek Sobczak (Orzecznictwo Sąu Najwyższego w sprawach protestów wyborczych), prof. nadzw. dr hab. Małgorzata Masternak-Kubiak i dr Agata Hauser (Dostęp do sadu w świetle kodeksu wyborczego), prof. nadzw. dr hab. Andrzej Bisztyga (Zakres kontroli Najwyższej Izby Kontroli wobec organów wyborczych oraz Krajowego Biura Wyborczego), prof. dr hab. Jerzy Jaskiernia (Kierunki pożądanych zmian polskiego prawa wyborczego w świetle raportów misji obserwacyjnych Organizacji Bezpieczeństwa $i$ Wspótpracy w Europie) oraz prof. nadzw. dr hab. Wojciech Orłowski (Administracja wyborcza w Polsce - stan obecny i propozycje zmian).

$\mathrm{W}$ drugim dniu obrad odbyły się ponadto trzy sesje panelowe. Pierwszej z nich, poświęconej wyborom samorządowym, przewodniczył prezes SKO w Zielonej Górze Robert Gwidon Makarowicz, a referaty zaprezentowali: mgr Jacek Ronowicz (Utrata prawa wybieralności lub brak tego prawa w dniu wyborów jako przestanka wygaśnięcia mandatu radnego jednostki samorzadu terytorialnego oraz wójta), dr Nina Leśniak-Niedbalec (Problemy prawa wyborczego przy zmianach granic gmin), dr Anna Frydrych-Depka i dr Maciej Serowaniec (Wybory niesporne $w$ polskim samorzadowym prawie wyborczym) oraz dr Zbigniew Woźniak (Rola sadownictwa powszechnego w procesie wyborczym). W kolejnej sesji edukacyj- 
nej, pod przewodnictwem prof. dr. Gaetano Dammacco, wystąpili: prof. dr Teresa Freixes (The European of Legal Education: The Project of a Common Semester in Public Law for All European Coutries), dr Francesco Dammacco (Summing up and Reviewing Boogs and Articles for the Leeds of Legal Research and of Legal Profession) i dr Veysel Dinler (The Preparation of the Law Students to Study Abroad: The Example of Turkey). W czasie ostatniego tego dnia panelu, któremu przewodniczył prof. dr Ioan Ganfalean, głos zabrali: prof. dr Miruna Tudorascu i prof. dr Ioan Ganfalean (New elektoral code Projekt in Romania. Will it become a law?), prof. dr. Berndt Wieser (Political Elections in Austria) oraz dr Anna Rytel-Warzocha (Polish Electoral Law in the Jurisprudence of the Constitutional Tribunal).

Sesji plenarnej podczas ostatniego dnia zjazdu przewodniczył prof. dr hab. Kazimierz Działocha. W tej części swoje wystąpienia zaprezentowało trzech referentów: prof. dr hab. Mariusz Jabłoński (Realizacja praw wyborczych przez osoby niepetnosprawne (kwestie dyskusyjne)), dr Anna Rakowska-Trela (Dlugość kampanii wyborczej - znaczenie, obowiqzujaca regulacja, propozycje de lege ferenda) oraz prof. nadzw. dr hab. Piotr Uziębło (Prawne gwarancje zasady powszechności wyborów a wyzwania współczesności).

W czasie Zjazdu odbyło się również kilka formalnych spotkań, a mianowicie posiedzenie Komitetu Redakcyjnego „Przeglądu Prawa Konstytucyjnego”, posiedzenie Kolegium Redakcyjnego „Przeglądu Sejmowego”, zebranie Polskiego Towarzystwa Prawa Konstytucyjnego i zebranie kierowników Katedr Prawa Konstytucyjnego.

Owocem zjazdu jest praca zbiorowa pod red. B. Banaszaka, A. Bisztygi, A. Fei-Paszkiewicz, Aktualne problemy prawa wyborczego wydana nakładem Oficyny Wydawniczej Uniwersytetu Zielonogórskiego (2015), w której znalazły się wszystkie referaty zgłoszone na konferencję i zaprezentowane przez uczestników.

Pawet Kuczma 